\title{
Who does Bolsonaro listen to under emergency conditions? Building a framework for analyzing informal presidential advisory networks during the Covid-19 pandemic in Brazil ${ }^{1}$
}

\author{
¿A quién escucha Bolsonaro en contexto de emergencia? Construyendo un marco \\ analítico para el estudio de las redes informales de asesoría presidencial durante \\ la pandemia de Covid-19 en Brasil
}

\author{
Aglaé Isadora Tumelero ${ }^{2}$ \\ Universidade Federal de Minas Gerais, Brasil
}

\begin{abstract}
RESUMEN A pesar de las evidencias sobre los asesores informales de los presidentes en América Latina, la literatura sobre el tema aún es incipiente. Este artículo investiga el escenario informativo que rodeó al presidente brasileño, Jair Bolsonaro, de enero a abril de 2020, un período de toma de decisiones presidenciales sobre las medidas para combatir la pandemia de Covid-19. Para eso, se realiza un estudio de caso de las interacciones establecidas por el presidente brasileño basado en los registros de la Agenda del Presidente. Se utilizan herramientas de análisis de redes sociales (SNA) para examinar las evidencias. Los resultados indican que el Ministerio de Salud no fue el principal canal de información del presidente al princípio de la pandemia a pesar de su papel central en la estructura de gobernanza nacional de emergencia em salud pública. Además, revelan la elección del presidente de utilizar la presidencia como su principal soporte informativo, incluso fortaleciéndolo a través de sus poderes
\end{abstract}

1. A previous version of this paper was presented at the XII Meeting of the Brazilian Association of Political Science, October 19-23, 2020, and a previous revised version at the VIII Meeting of Mexican Association of Political Science, December, 8-11, 2020. I thank the panelists of both events and the anonymous reviewers of Revista Chilena de Derecho y Ciencia Politica for their valuable comments on the manuscript.

2. Aglaé Tumelero is a PhD Candidate at Universidade Federal de Minas Gerais (Brasil). She is currently carrying out doctoral research with a focus on the effects of institutional rules and policy preference on presidential information strategies in Latin America. E-mail: aglaeisadora@c-pol. mest.ufmg.br. ID https://orcid.org/0000-0003-2883-769X 
administrativos unilaterales. Finalmente, no hay evidencia de que el Presidente combinara el asesoramiento formal e informal como estrategia de acceso a la información alternativa al Ministerio de Salud, resultados que deben ser sopesados considerando el carácter parcialmente confiable de la Agenda del Presidente como fuente de evidencia relacional. El estudio ofrece un marco conceptual y metodológico para identificar y medir la estrategia de asesoría informal de los presidentes brasileños, contribuyendo al avance teórico y metodológico de la investigación sobre el tema en América Latina.

PALABRAS CLAVE Redes Informales; Asesoría Presidencial; Poder Ejecutivo; Covid-19; Brasil.

ABSTRACT Despite evidence about the informal advisors of the presidents in Latin America, literature on this topic is still incipient. This article investigates the informational scenario that surrounded the Brazilian president, Jair Bolsonaro, from January to April 2020, a period of presidential decision-making on the measures to face the Covid-19 pandemic. In-depth case study of interactions established by the Brazilian president is developed based on data from the Brazilian President's Daily Diary. Social Network Analysis (SNA) tools are used to analyze this evidence. The findings suggest that the Ministry of Health $(\mathrm{MOH})$ was not the main information channel for the president at the beginning of the pandemic despite its central role in the national governance structure of public health emergencies. In addition, the analysis shows the president's choice to use the structures of the Presidency as main informational support, including strengthening them through unilateral administrative measures. Finally, the results indicate that there is no evidence that the president combined formal and informal advisory as a strategy to access alternative information to the $\mathrm{MOH}$. The findings should be pondered regarding the partly reliable nature of the President's Daily Diary as a source of relational data. The study provides a conceptual and methodological framework to identify and measure the presidential informal advisory strategy, contributing to the advance of research on presidential advising in Latin America.

KEYWORDS Informal Networks; Presidential Advisory; Executive Branch; Covid-19; Brazil. 


\section{Introduction}

Literature on institutional presidency in Latin America has focused on a set of tools available to presidents to solve the informational challenges made by multiparty government dynamics. Special emphasis has been given to the tools derived from the formal powers of the presidents, especially the administrative and appointment powers. Anecdotal evidence suggests that informal strategies, such as informal advisory networks, also help the presidents of the region to solve the informational challenges and strengthen their leadership skills. However, there are few studies of the topic and even fewer methodological and conceptual discussions of how to identify and measure informal advisory networks.

This article seeks to answer the following research question: How to measure informal presidential advisory strategy? Based on the previous research agenda as a logical point of departure, the article offers a conceptual and methodological framework to identify and measure the informal presidential advisory strategy. First, informal advisory strategy is defined here as the network of relationships established informally by the presidents with external actors in the public administration as a means of accessing and controlling information. Second, four indicators are proposed to measure it: (1) the type of meeting, (2) the organizational affiliation of the network actors, (3) the actors 'professional background, and, finally (4) the temporal precedence of meetings regarding the decisions and positions adopted by the Presidents.

To shed lights on this issue, a case study of the Brazilian president interactions from January to April 2020 is carried out. This period presents an accentuated episode of intra-executive conflict between the president and the head of the Ministry of Health $(\mathrm{MOH})$ on the responses to face the pandemic. Using evidence from the Brazilian President's Daily Diary, 484 interactions involving the president are analyzed and the president's relational ties with civil society actors are examined using the Social Network Analysis (SNA) tools.

The findings suggest that, at least in the initial period of pandemic in Brazil, the presidency structures, especially the Civil House, the Government Secretariat and the Presidency Secretariat, were the main informational support of the president, playing a central role in the presidential advisory network. Moreover, the study suggests that the conflict of preference within the cabinet in the context of the national emergency was not enough incentive for the adoption of an informal advisory network.

The article contributes to the methodological and theoretical discussions on informal presidential advising in Latin America. It is organized in five different and special sections not including this one. It begins with a brief literature review on formal and informal presidential information strategy. It goes on to provide a discussion of case selection and the chronology of events of the period, followed by a brief methodological discussion on the sources of evidence used in research on presiden- 
tial advisory and the analytical tools used to analyze them. This section is followed by in-depth case study of interactions established by the Brazilian president in the first four months of the Covid-19 pandemic in this country. The conclusion reports the study's findings and contributions.

\section{Literature Review}

The access of information is a fundamental element for presidential decision making. In political philosophy, the discussion on the art of being informed and advised has a long history ${ }^{3}$. The information is considered the vital force of decision making and constitutes the essential need of leaders ${ }^{4}$. "Information is power because it is the substance of which decisions are made" ${ }^{5}$. Even experienced leaders cannot be specialists in everything, and therefore, they depend on information and advice, constantly needing assistance to gain information and how to use it $^{6}$.

The control of information is also an important element for presidents in their efforts to promote governability; that is, the capacity to manage and control the state. It is through information control that presidents are able to exercise their legislative powers, increase political influence, reduce uncertainty and control the negotiating environment within the government, ensuring that their decisions are implemented ${ }^{7}$. Control of information provides them capacity for effective leadership.

Controlling information, in turn, requires strategy. The literature on institutional presidency points out that the leaders of presidential governments have at their disposal powers that allows them to obtain access and control of information through structural choices, particularly administrative and appointment powers ${ }^{8}$. The politicization and centralization are the main formal strategies to reach full control of information.

Politicization refers to the practice of placing loyal, partisan or ideologically compatible political appointees in bureaucratic positions of ministries, agencies and departments of the Executive Branch in order to control information related to policies $^{9}$. "The central idea is to ensure that important bureaucratic decisions are made by presidential agents, or at least are directly overseen and monitored by them" ${ }^{10}$.

3. GOLDHAMER (1978); MELTSNER (1990); MAQUIAVEL (2013).

4. NEUSTADT (1991); KOWERT (2002).

5. WITHERSPOON (1991) p. 149.

6. THOMAS (1970); KOWERT (2002).

7. MOE (1993).

8. MOE (1985, 1993, 2000); RUDALEVIGE (2002); LEWIS (2003); RUDALEVIGE y LEWIS (2005); INÁCIO y LLANOS (2016).

9. $\operatorname{MOE}(1993)$.

10. MOE (1993) p. 370. 
Centralization is based on limiting the discretionary power of executive ministries or agencies and transferring decision making power to the President, which can be done by transferring agencies responsible for important decisions and policies to the Presidency, removing them from the authority of ministers or agencies. Besides, another way to centralize is to create political structures within the Presidency, incorporating people from other departments and agencies, and pulling highly salient policy issues to the presidency for consideration, debate and resolution ${ }^{11}$.

Literature on institutional presidency has found that structures to control information created at the Presidency are heterogeneous. In the United States, presidents from Hoover to Nixon, for example, adopted different structural patterns: public commissions, task forces, and conferences, all of which operated for a limited time period, and permanent advisory bodies, such as the Council of Economic Advisers (CEA) and the President's Science Advisory Committee (PSAC), which are positioned in the Executive Office of the President (EOP $)^{12}$.

Centralization is also used by Latin American presidents. Research shows that the quantity of structures created at the Presidency has oscillated among countries of the region since democratic transition. While Paraguay and Uruguay show a linear movement of expansion in the number of these structures, other countries such as Argentina, Brazil, Colombia and Mexico show a nonlinear movement marked by declines and increases ${ }^{13}$.

Still, the type of structures centralized at Presidency vary in the region. INÁCIO (2013) classified these structures into three groups: core, advisory, and policy. The core structures comprise the units responsible for conducting, within the scope of the presidency, the activities of coordination, monitoring and integration of government actions, at different levels: legal, administrative and institutional, including internal and external coordination. The advisory structure is oriented towards the formulation of policies and strategic agendas. In turn, the policy structure is responsible for formulating and implementing specific policies ${ }^{14}$.

Research also points out that the number of each type of structure also varies ${ }^{15}$. Between 1984 and 2010, for example, the Argentine Presidency was internally not so diversified oscillating only between core and policy structures. In the same period, in turn, the Brazilian Presidency presented core, policy and advisory structures ${ }^{16}$. Especially the expansion of advisory structures was markedly a non-linear process in Brazil from 1990 to 2019 as figure 1 shows.

11. MOE (1993) p. 371.

12. THOMAS (1970).

13. INÁCIO y LLANOS (2016).

14. INÁCIO (2013).

15. INÁCIO y LLANOS (2015).

16. INÁCIO y LLANOS (2015). 
Figure 1. Advisory structures centralized at the Presidency of Brazil (1990-2019).

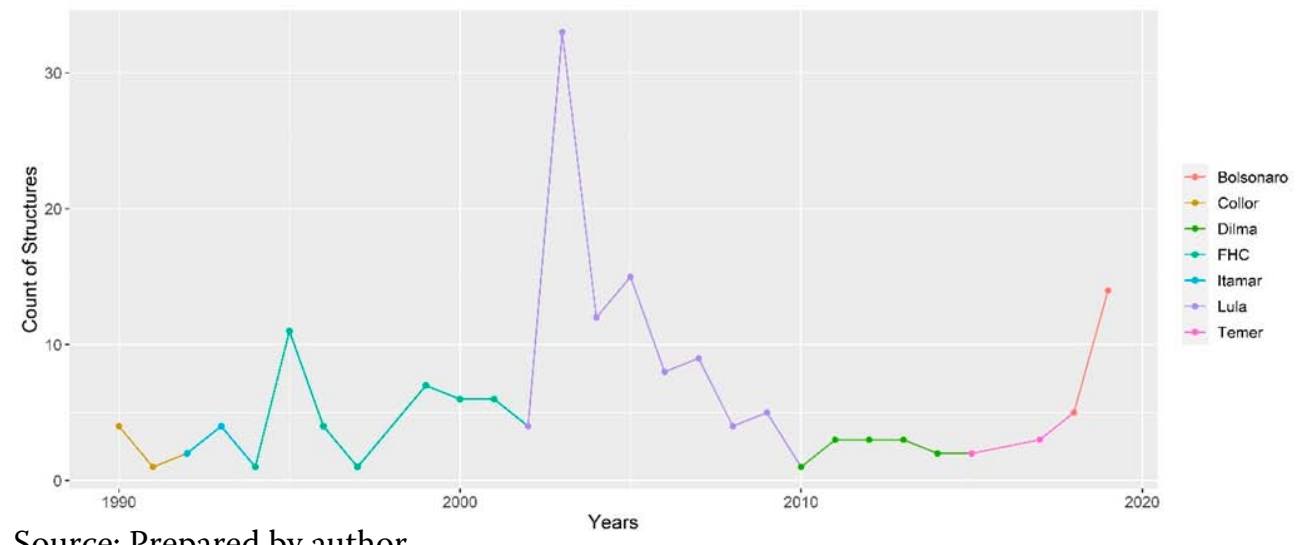

Source: Prepared by author.

Centralization and politicization are possible due to formal powers of presidents, especially their administrative and appointment authority. These powers allow presidents (by their own choice) to make important structural choices without going through the legislative process, altering the dynamics of institutional change and fashion a system more to their liking. It is through these powers that U.S. and Latin American presidents can organize and direct the Presidency as they see fit, creating structures, reorganizing them, moving them, coordinating them, imposing rules about their behavior, and putting their own people in top positions ${ }^{17}$. Thus, these formal powers are incentives and institutional opportunities for presidents to create their own context, increasing their leadership capacity ${ }^{18}$.

The presidents may secure control of information and promote governability in another way, particularly by mobilizing an informal network of aides ${ }^{19}$. This information strategy receives different terms in different countries. In the United States, it has been called 'inner-circle,' 'kitchen cabinets' and 'invisible presidency'. In turn, 'Círculo de Hierro' and 'Segundo Piso' in Chile. The main goal of this strategy is to provide "the President with broad gauge advice on critical policy choices that is unrestrained by departmental, agency, or pressure group interests" ${ }^{20}$.

In Latin America, the use of formal powers and informal advisory networks by the presidents to access information is associated with the challenges that the dynamics of multiparty governments pose for the principal-agent relationship. Particularly in Argentina, Brazil, Colombia, Mexico, Paraguay and Uruguay, centralization

17. MOE (1993); MOE y CALDWELL (1994).

18. $\operatorname{MOE}(1993 ; 2009)$.

19. THOMAS (1970); LINK y KEGLEY (1993); MÉNDEZ (2007); SIAVELIS (2016).

20. THOMAS (1970) p. 561. 
is encouraged by the number of parties in the cabinet and the heterogeneity of preferences between them ${ }^{21}$. The mentioned factors complicate the delegation between the president and the ministers (agents), and expose presidents to greater chances of agency losses, especially moral hazard ${ }^{22}$. To avoid agency losses, presidents centralize decision making and other tasks within the presidency. Through this strategy, presidents expand their legislative and appointment powers, protect themselves from cross-party consultation, and increase their policy influence ${ }^{23}$.

In turn, research on Chile politics points out that multiparty power sharing arrangements provide incentives for the mobilization of informal advisory networks ${ }^{24}$. These arrangements, when driven by a set of challenging rules such as age, expertise, gender, proportionality and transversality, limit the presidential appointments, and encourage presidents to rely on advisers outside the ministries and the presidency. Thus, "the informal advisory networks are the way presidents balance portfolio sharing with their need for information and advice" 25 .

\subsection{Defining presidential informal advisory networks}

Literature on presidency shows two definitions for this strategy. First, as informal interactions that presidents establish with a small number of formal advisers (who hold positions in the ministries and agencies of the Executive Branch) and personal friends. These interactions occur in ad hoc meetings, as well as in semi-formal gatherings like working breakfasts or lunches ${ }^{26}$. Second, as an informal advisory network that is kaleidoscopic, that is, whose pattern of interaction and composition changes continuously. This network consists on presidents and members that can be individuals serving in or outside of the cabinets, in other presidential offices, or be completely informal advisers with no statutory or formal appointment ${ }^{27}$.

Joining this previous research agenda, is presented here a concept of informal advisory strategy from the following three analytical attributes: (1) relational choices, (2) non-regulation by legal measures and (3) network structure. For this reason, the informal advisory strategy refers to the network of relationships established by the presidents with small group of actors, who are external to government, as a means of accessing and controlling information. These interactions are not regulated by a legal

21. BATISTA (2013); GAYLORD y RENNÓ (2015); INÁCIO y LLANOS (2016).

22. Moral hazard is a post-contractual opportunistic behavior, in which agents (here ministers) take advantage of the information asymmetry, acting for their own benefit or that of their group at the expense of the principal's preferences (here presidents) MOE (1985); RUDALEVIGE (2002).

23. INÁCIO y LLANOS (2016).

24. SIAVELIS $(2014 ; 2016)$.

25. SIAVELIS (2016) p. 02.

26. THOMAS (1970); LINK (2002).

27. SIAVELIS (2016). 
provision and the network is constantly changing, with relationships being activated and deactivated at any time.

While centralization and politicization involve structural choices by presidents about which structures to create and which positions to politicize in order to control information, the informal advisory strategy involves choosing who to listen to, who to-relate-to and who to allow access to. I consider it a relational choice, because it refers to the set of actors that the presidents choose to relate in order to access relevant information for decision making process.

The choice of the set of actors to listen to and the informational function they perform does not become a written and sanctioned rule within official channels, although it is socially shared and communicated within those channels. Thus, while centralization and politicization have functions and rules written and sanctioned in these channels, being possible to identify them through formal measures, the informal advisory strategy is not regulated by written rules. This means that the aides' advisory role and their relationship with the president is informal ${ }^{28}$.

The structure underlying the informal advisory strategy is a network, that is, a set of specific relationships between a finite set of actors ${ }^{29}$. The set of relationships in this network are advisory relationships and its actors are those selected by the presidents. These relationships operate as a channel for transferring and exchanging information - a fundamental immaterial resource for decision making and governability.

Identifying and measuring informal strategies is not simple - "identify, measure and compare the rules of the game that are not written and, in many cases, hidden from the public"30. Similarly, advisory networks are not explicit, neither written. Informal advisors do not provide information to presidents through memos or written reports that can be tracked, but through physical or virtual interactions in small groups that are not regulated by a legal provision.

Literature on informal advisory networks in Latin America is incipient, not presenting accumulated theoretical and methodological development. Thus, this article offers a contribution by building a methodological framework to identify and measure it. In order to explain this point, the empirical strategy adopted is a case study of Brazil in the first four months of the Covid-19 outbreak. The following sections set out this analytical way.

\section{Case selection}

The close examination of Brazil over a four-month period (January-April 2020) offers an interesting opportunity to study presidential information strategy. First, the period of analysis encompasses the beginning of the coronavirus' outbreak in the

28. HELMKE y LEVITSKY (2006).

29. WASSERMAN y FAUST (1994).

30. HELMKE y LEVITSKY (2006) p. 04. 
country and the first government's responses to it, which included measures of social distancing, quarantine and different treatments of the disease, particularly the guidelines for the use of chloroquine and hydroxychloroquine.

Second, the period is marked by repeated conflicts between the position of the $\mathrm{MOH}$ and the Presidency on the content of these measures. The dismissal of the Health Minister, Luiz Henrique Mandetta, in the mid-April highlights the end of this conflict. The dismissal also resulted in an administrative discontinuity of the management of health emergency.

The case presents an accentuated episode of intra-executive conflict combined with Bolsonaro's refusal to make the $\mathrm{MOH}$ his main source of advice in decisionmaking during a severe health emergency. Based on literature on presidency, it is expected that these conditions produce incentives to the mobilization of an informal advisory network by the president. This section presents the main events and decisions that marked the period. The figure 2 shows the chronology of events.

Figure 2. Chronology of the responses by Brazilian Government from January to April, 2020 ${ }^{31}$.

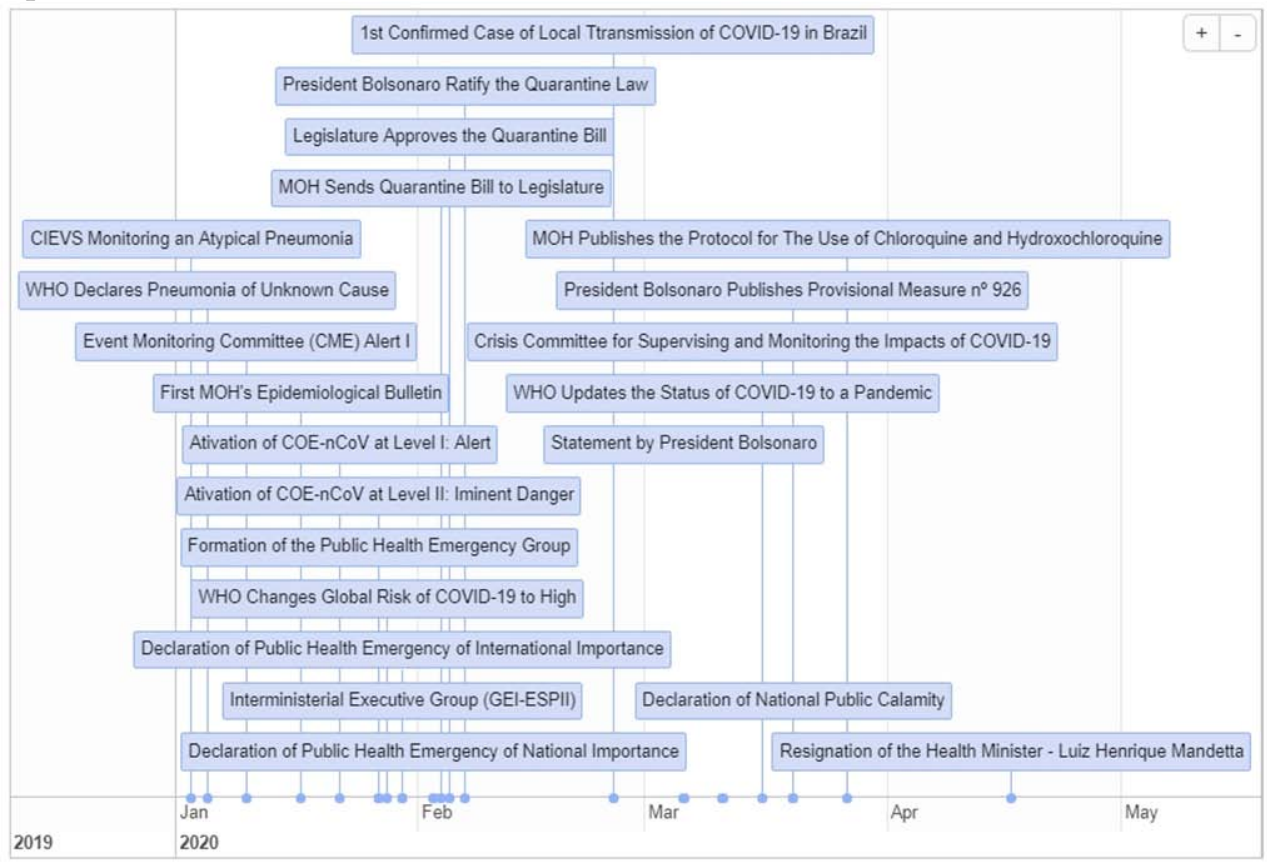

Source: Prepared by author.

31. Figure 2 can be seen interactively here: https://doi.org/10.6084/m9.figshare.14740818.v1. 
On February 3, the State of Public Health Emergency of National Importance (ESPIN) was declared by the Health Minister, four days later the World Health Organization (WHO) declares the outbreak of Covid-19 as an International Public Health Emergency (ESPII) ${ }^{32}$.

The ESPIN can be declared only by an act of the Health Minister after requisition of the Secretary of Health Surveillance or, in the event of a disaster, by the Integration National Minister ${ }^{33}$. For its declaration, it is also necessary to present to $\mathrm{MOH}$ a technical report with information on the risk of spreading the disease, level of severity of the emergency, rates of morbidity, lethality and contamination and a description of the environmental aspects of the event ${ }^{34}$.

Briefly, prior declaring the ESPIN, a series of monitoring measures of the Covid-19 outbreak were taken by the $\mathrm{MOH}$ and the National Secretariat of Sanitary Surveillance (SVS). In particular, seven measures foreseen in the Public Health Emergency Response Plan (PRESP) were adopted ${ }^{35}$. The first of them was the requisition for a "rumor check" about the disease in China by Center for Strategic Information in Health Surveillance (CIEVS) ${ }^{36}$. The second measure was the triggering of the Event Monitoring Committee (CME) to monitor the outbreak of Covid-19 in China, after confirmation of a new virus on January $10^{37}$. The third was the publication of the first SVS Epidemiological Bulletin with information about the new disease. The fourth measure was the activation of the Public Health Emergency Operations Center for the New Coronavirus (COE-nCoV) for alert level I. The fifth was the change of COE$\mathrm{nCoV}$ in national alert level from I to II after confirmation of the first suspected case of infection in Brazil. In addition, the Public Health Emergency Group was created to conduct the actions related to the new coronavirus ${ }^{38}$. Finally, the creation of the Inter-ministerial Executive Group on Public Health Emergency of International Importance (GEI-ESPII) ${ }^{39}$.

\section{Portaria 188, de 2020.}

33. Decreto 7.616, de 2011 y Portaria 2.952, de 2011.

34. Portaria 2.952, de 2011.

35. The PRESP, approved in 2014, provides guidelines for the actions of SVS and MOH in the face of public health emergencies. Together with the National Policy for Civil Defense and Protection, approved in 2012, it is part of the national structure governance of disasters Ley 12.608, 2012; Ministério da Saúde, 2014. This structure internalizes the international commitments agreed by Brazil with World Health Organization (WHO), particularly International Health Regulations (IHR) RODRIGUES, CARPES y RAFFAGNATO, 2020.

36. RODRIGUES et al. (2020).

37. CRODA y GARCIA (2020).

38. By Ordinance No. 74, 2020 of the National Health Surveillance Agency (ANVISA).

39. By Decree No. 10.211, 2020. 
After ESPIN, the Health Minister sent to the National Congress a Bill of Law providing sanitary measures to combat the outbreak, such as social distancing and quarantine, and the eventual closure of ports, highways and airports for entering and leaving the country. On February 5th, the bill was voted by the National Congress, becoming the Law 13.979/2020 (namely Lei da Quarentena). Also, the first case of local transmission of the virus was confirmed, inaugurating a new phase of the emergency management cycle in Brazil - $\mathrm{MOH}$ published the treatment protocol for the new coronavirus on February $26^{40}$.

Throughout January and February, while the $\mathrm{MOH}$ and their specialized bureaucracies followed international recommendations and protocols in the initial pandemic response, the President made repeated public statements minimizing the magnitude of the situation and criticizing the social distancing measures to contain the virus contamination curve. From January to March, the president announced twenty-seven public statements attenuating the risks of the new coronavirus and criticizing the social distancing measures. In particular, his official statement in the national radio and television networks consolidated the conflict between the $\mathrm{MOH}$ recommendations and the Presidency's position ${ }^{41}$.

The conflict between the $\mathrm{MOH}$ and the Presidency reached new dimensions with the unilateral measures issued by the president Bolsonaro on March, 2020. The first of them was the centralization of the Crisis Committee for Supervision and Monitoring of the Impacts of Covid-19. This was an advisory structure subordinated directly to the Presidency and not foreseen in the Brazilian disaster governance structure. Its original purpose was to articulate government action and advising the President on issues related to pandemic - a president strategy to monitoring $\mathrm{MOH}^{42}$. Three months later, the Committee gained decision rights, such as to deliberate on priorities, guidelines and strategic aspects of tacking the Covid-19. This change resulted in the emptying of the $\mathrm{MOH}$ decision rights ${ }^{43}$.

The second unilateral measure of the president was the Provisional Measure 926/2020 (MP). The MP established as exclusive right of Federal government to legislate on social distancing and quarantine measures, modifying the article 3 of the Lei da Quarentena. The MP was a reaction of the President Bolsonaro to the tightening of social distancing measures adopted by the subnational governments. Faced with the expressive increase in the rate of infection and deaths from Covid-19, the

40. BRASIL. Ministério da Saúde. Protocolo de Tratamento do Novo Coronavírus (2019-nCoV).

41. Available in: https://www.gov.br/planalto/pt-br/acompanhe-o-planalto/pronunciamentos/pronunciamentos-do-presidente-da-republica/pronunciamento-do-senhor-presidente-da-republicajair-bolsonaro-em-cadeia-de-radio-e-televisao-3 [Date of access: 10/01/2021].

42. Decreto 10.277, de 2020.

43. STARGARDTER y EISENHAMMER (2020). 
governors of São Paulo and Rio de Janeiro states followed the guidelines of the $\mathrm{MOH}$ and closed public school system, as well the operation of shopping malls, gyms, and in person attendance at commercial establishments. The MP generated a reaction of governors and mayors, who did not follow through. Also, the MP was questioned in Direct Constitutionality Action (ADI 6.341/2020) in the Federal Supreme Court (STF). On April 16, 2020 the Court reaffirmed the shared competence of national and subnational governments in tackling the pandemic, which represented a setback for President Bolsonaro.

The intra-executive conflict between the President and the head of $\mathrm{MOH}$ intensified with the publication of the treatment protocol for the new coronavirus by $\mathrm{MOH}$, providing guidance on the prescription of chloroquine and hydroxychloroquine in the treatment of severe cases of Covid- $19^{44}$. The publication occurred six days after the declaration of the state of community transmission of the virus in Brazil. The $\mathrm{MOH}$ protocol was based in WHO recommendations for the use of the medicine, which displeased the presidency. President Bolsonaro has been defending the widespread use of chloroquine and hydroxychloroquine, especially in the treatment of mild cases of Covid-19. The disagreement culminated in the dismissal of the Health Minister, Luiz Henrique Mandetta, and the National Secretary of Sanitary Surveillance, Wanderson de Oliveira in mid-April.

Brazil is an exceptional case of intra-executive conflict marked by divergences between the presidency and the portfolio in charge of public health emergency management. Despite $\mathrm{MOH}$ leading the outbreak response, monitoring its evolution in Brazil and the world since the beginning of the outbreak, it was not mobilized as the main information channel by President Bolsonaro. So, the Brazilian president's behavior raises the questions: who did the president listen to in decision making about social distancing measures and the protocol for the use of chloroquine and hydroxychloroquine? What were his sources of information?

Thus, regarding the chronology of the events and the literature on the topic, my argument is that the period from January to April offers a fertile ground for the mobilization of informal advisory network by the president Bolsonaro. In other words, seeking to reduce the bias of the $\mathrm{MOH}$ information, the president would have incentives to invest in an informal advisory strategy, which would provide him an alternative channel for transferring and exchanging information about the Covid-19 outbreak.

44. BRASIL. Ministério da Saúde. Nota Informativa No. 5/2020. Uso da Cloroquina como terapia adjuvante no tratamento de formas graves do COVID-19. 


\section{Data and measure}

Studies on presidents' interaction with their aides usually relies on three sources of evidence: data from official schedules of the President's Daily Diaries ${ }^{45}$ and press and interview data ${ }^{46}$.

The first source of evidence is used in studies on the U.S. presidency. Maintained by the National Archives, the official schedules of the Presidents' Daily Diaries list on a minute-by-minute basis nearly all of Eisenhower, Kennedy, Johnson, Nixon, Ford and Carter presidents' contacts with other individuals, including both telephone conversations and in-person meetings. These notes provide researchers with six essential information: occurrence, date, duration and generally the type of meeting, in addition to a list of the number and identity of those present ${ }^{47}$.

Social network analysis has been used to analyze the evidence about presidentadvisor interactions from official schedules of the Presidents' Daily Diaries ${ }^{48}$. LINK (2002) argues that "relationships between a president and his advisers can be viewed as a kaleidoscopic network of individuals in that they are complex and varied" 49 . The author also points out that Presidents' Daily Diaries are a detailed source for analyzing presidential networks. Thus, using the SNA measures, he explores the variation in the size of the network of advisors from Carter to Nixon, who were the advisors who interacted most with each president, as well as the turnover of actors in the advisory network of these presidents ${ }^{50}$.

45. THOMPSON (1990a, 1990b, 1990c); BEST (1988, 1992); SIGELMAN y MCNEIL (1980); LINK y KEGLEY (1993); LINK (2002).

46. ARANA (2012); SIAVELIS (2016).

47. LINK y KEGLEY (1993).

48. In addition, several studies have relied on descriptive measures to analyze the pattern of interaction between U.S. presidents and their advisers, which have focused on: the number of times particular senior members of Carter's White House staff participated in group or one-on-one meetings with president, the total amount of time spent in these interactions THOMPSON (1990a, 1990b, 1990c), the simple frequency of interactions between president Johnson and his foreign policy advisers during Tet crisis, the last average, in minutes, of all the interactions during this crisis SIGELMAN y MCNEIL (1980); BEST (1988, 1992), the quantity of instances or occurrences of advisers meeting with president Carter, and the time adjusted (indexing the total time to a standardized measure based on the total number of people attending these meetings) LINK y KEGLEY (1993).

49. LINK (2002) p. 237.

50. LINK (2002). 
The second source of evidence, that is, press and interview data, is used for researching purposes on the interaction between Latin American presidents and their advisors. This evidence was analyzed based on theoretically grounded case study ${ }^{51}$ and content analysis ${ }^{52}$. By theoretically grounded case, study compare the composition of the advisory network of Chilean presidents between the administrations of Patricio Aylwin $^{53}$, Eduardo Frei, Ricardo Lagos and Michele Bachelet. By content analysis, studies analyze the response of twenty-one former Latin American presidents from eight countries to the question: "Suppose you want to make a decision, but you don't have all the background you would like to make an informed decision, what would you do? Would you follow your instincts, ask for advice, or refrain from making a decision?"54.

Based on these previous studies, the Brazilian President's Daily Diary is used as a source of evidence about informal interaction president-advisors. This source provides well documented relational data, publicly available, ensuring replicability ${ }^{55}$. Particularly, it presents five kinds of information: type of meeting, usually a list of the identity of those present, local, date and time ${ }^{56}$.

It is important to clarify that the data from Brazilian President's Daily Diary is limited. First, phone calls or emails exchanged between the president and his aides are not recorded on the official schedule. Second, scheduled meetings that, for whatever reason, did not happen are not registered as "cancelled" or "suspended" on the schedule, but they are deleted of it. Finally, the schedule is coordinated by Gabinete Pessoal do Presidente ${ }^{57}$, which is formed by loyal agents of him. Hence, presidents have complete discretion over the schedule, so they can choose not to publicize the information.

51. SIAVELIS (2016).

52. ARANA (2012).

53. SIAVELIS (2016).

54. ARANA (2012) p. 36.

55. Data were collected in Brazilian Government Open Data Portal: http://dadosabertos.presidencia.gov.br/dataset/agendas-presidenciais-2020.

56. Supplemental material for this paper is available here: https://figshare.com/projects/Who_ does_Bolsonaro_listen_to_under_emergency_conditions_Building_a_framework_for_analyzing informal_presidential_advisory_networks_during_the_Covid-19_pandemic_in_Brazil/99449.

57. This function is regulated by Law 13.844, 2019. 
Table 1. Excerpts from President Bolsonaro's Daily Diary of Activities (April 17, 2020).

\begin{tabular}{|c|c|c|l|}
\hline Local & To & From & \multicolumn{1}{c|}{ Activity } \\
\hline Brasília & $09: 00$ & $10: 00$ & $\begin{array}{l}\text { Braga Neto Civil House Minister } \\
\text { Luiz Eduardo Ramos Government Secretariat Minister }\end{array}$ \\
\hline Brasília & $11: 00$ & $12: 00$ & Inauguration Ceremony of Mr. Nelson Luiz Sperle Teich \\
\hline Brasília & $14: 10$ & $14: 40$ & Wagner Rosário Comptroller General of the Union Minister \\
\hline Brasília & $15: 10$ & $15: 40$ & $\begin{array}{l}\text { Braga Neto Civil House Minister } \\
\text { Luiz Eduardo Ramos Government Secretariat Minister } \\
\text { Rogério Marinho Regional Development Minister }\end{array}$ \\
\hline Brasília & $16: 45$ & $17: 00$ & Jorge Antonio de Oliveira Presidency Secretariat Minister \\
\hline Brasília & $17: 00$ & $17: 20$ & $\begin{array}{l}\text { Braga Neto Civil House Minister } \\
\text { Luiz Eduardo Ramos Government Secretariat Minister } \\
\text { Jorge Antonio de Oliveira Presidency Secretariat Minister }\end{array}$ \\
\hline Brasília & $17: 20$ & $17: 45$ & $\begin{array}{l}\text { Luiz Eduardo Ramos Government Secretariat Minister } \\
\text { Jorge Antonio de Oliveira Presidency Secretariat Minister } \\
\text { Mr. Nelson Luiz Sperle Teich }\end{array}$ \\
\hline
\end{tabular}

Source: Prepared by Author Based in Bolsonaro's Daily Diary.

To find the informal presidential advisory network, four indicators are used yet. First, the type of meeting. Literature on institutional presidency indicates that informal advisory relationships usually occur in one-on-one and small group meetings ${ }^{58}$. In addition, these types of meetings have a less formalized character, without a protocol limiting the interaction between the actors ${ }^{59}$. Thus, one-on-one and small group meetings are considered here as an indicator of informal advisory networks mobilized by presidents.

The second indicator is the organizational affiliation of the actors who interact with the president in these types of meetings. This is an important aspect because it indicates the president's linking with actors and whether they play a legal informational role. In Brazil, for example, ministers, presidential staff and directors of executive agencies have the duty to give information to the president through annual management reports. Similarly, the leaders and vice-leaders of government in Legislature have agenda power and information conditions to monitor deputies ${ }^{60}$. These leaders are chosen by the president and generally play an informational role in aligning the government's agenda in the Legislature. In this way, actors inside the government

58. THOMAS (1970).

59. LINK y KEGLEY (1993).

60. Powers provided by the statutory right to participate in the work of any committee and the provision to be consulted in the selection of proposals that will be considered each month (Art. 11 and Art. 17 of the Internal Regulations of the Chamber of Deputies of Brazil). 
have a formal advisory role, while external actors can have an informal advisory role in policy decision-making ${ }^{61}$.

However, not all external actors with whom the president interacts are channels of information for policy decision-making. The president's interaction, regarding external actors, can be a strategy to signal his preferences to his electoral base or his allies and interest groups. Thus, the third and fourth indicators are the actors' professional background and the temporal precedence of the meetings to the presidential decisions relative to the outstanding issues at the time, respectively. My argument is that both indicators mark the informational role of external actors in policy decisionmaking. Thus, the informal presidential advisory network is identified through interactions established by the president with actors external to the government in oneon-one and in small group meetings that occurred before crucial decisions making by the presidents.

To illustrate the point on actors' professional background, two brief examples. In a health emergency where decisions on measures to contain the spread of the virus are on everyone's eyes, the interaction of the president in one-on-one and in small groups meetings with civil society actors linked to the health area is a way to access and interchange the information. Similarly, in the context of an external crisis, such as the Tet Offensive in Vietnam, the Cuban Missile Crisis, the September 11 in the US, the president's interactions with actors linked to the foreign policy area has been used to understand the caliber of information that had help the presidents make decisions ${ }^{62}$.

Finally, descriptive statistics measures and SNA tools are used for data analysis ${ }^{63}$. SNA has been used in an innovative way in research on informal political institutions, especially patronage and policy formulation in authoritarian regimes ${ }^{64}$. These studies show that informal institutions have a strong relational component, pointing out the advantages of SNA as a theoretical and empirical approach to analyze them. In addition, SNA has also been used in research on informal organizations, such as informal trade in developing countries ${ }^{65}$.

61. It is important to point out that the legal informational role of government actors should be understood in the context of each case. In Brazil, for example, the formation of a multiparty cabinet with a high ideological heterogeneity, a formula adopted by Brazilian presidents to overcome the institutional impasses caused by the difficult combination of presidentialism and multipartyism MAINWARING (1993); LINZ y VALENZUELA (1994); AMORIM NETO (1994, 2006), produces transaction costs and constraints in controlling information about policies for presidents. In other words, members of the cabinet and executive agencies, being subordinate to Their parties and the president, have incentives to use the informational advantages they have for the benefit of their party at the expense of the president's preferences.

62. ALLISON (1971); PIOUS (2001); T'HART et al. (2009).

63. WASSERMAN y FAUST (1994).

64. RAZO (2008); KELLER (2015a, 2015b).

65. WALTHER (2015). 


\subsection{Empirical results}

The meetings of the Brazilian president are classified in six types derived from an empirical observation. This is a crucial element in determining presidential access patterns ${ }^{66}$. These types are named as one-on-one meetings, small group meetings, social/ceremonial events, formal group meetings, working breakfasts/lunches and travel. One-on-one meetings consist of dyadic (individual) interactions between the president and other actors ${ }^{67}$. Small groups involve interactions between the president and a relatively small number of actors. Social and ceremony events refer to official events (i.e., Inauguration Ceremony, Hoisting of the National Flag, Official Banquets). Finally, formal group meetings consist of the president's interaction with formal groups (i.e. Council of the Republic, National Defense Council). The working breakfasts/lunches and travel are self-explanatory ${ }^{68}$.

The President's Daily Diary presents 589 meetings of the President Bolsonaro from January to April 2020. Among them, 45.5\% refers to one-on-one meetings and $36.7 \%$ refers to small group meetings of average 3 actors, not including the president. Bolsonaro's choice for one-on-one and small group meetings differs markedly from the choice of ex-president Fernando Henrique Cardoso, who predominantly opted for collective meetings. However, Bolsonaro's choice somehow resembles ex-president Dilma Rousseff's ${ }^{69}$. The count of one-on-one meetings of the first three years of Dilma's government (2011-2013) is greater than three hundred, while Bolsonaro's absolute value in the first four months of his second year of government is very close to three hundred as table number 2 shows.

66. LINK (2002).

67. LINK y KEGLEY (1993).

68. There is no data on each actor who interacted with the president for the last three types of meetings. Formal groups usually participate in these events, such as parliamentary benches.

69. BATISTA y CAVALCANTE (2018). 
Table 2 - Percentage of Type of Meeting, Average of Time Spent by President with Meetings, From January to April, 2020.

\begin{tabular}{|l|c|c|c|c|}
\hline \multicolumn{1}{|c|}{ Type of meetings } & $\mathbf{N}$ & $\%$ & $\begin{array}{c}\text { Average Time } \\
\text { Spent } \\
\text { in minutes })\end{array}$ & $\begin{array}{c}\text { Standard } \\
\text { Deviation } \\
(\text { in minutes })\end{array}$ \\
\hline One-on-One Meetings & 268 & 45.5 & 37 & 46 \\
\hline Small Group Meetings & 216 & 36.7 & 43 & 26 \\
\hline Social/Ceremonial & 74 & 12.6 & 44 & 27 \\
\hline Formal Group Meetings & 18 & 3.1 & 103 & 52 \\
\hline Working breakfasts/lunches & 9 & 1.5 & 66 & 17 \\
\hline Travel & 4 & 0.7 & - & - \\
\hline Total & 589 & 100.0 & - & - \\
\hline
\end{tabular}

Source: Prepared by author based on TUMELERO Database available in: https://doi. org/10.6084/m9.figshare.14200640.

In order to examine the Brazilian president's interactions at one-on-one and small group meetings, all the actors were categorized in terms of their organizational affiliation. This kind of information is available in the President's Daily Diary. Table number 3 below presents the nine categories of organizational affiliation.

Table 3 - Organizational Affiliations Categories.

\begin{tabular}{|c|c|c|}
\hline $\begin{array}{l}\text { Organizational } \\
\text { Affiliations }\end{array}$ & Abbreviation & Actors \\
\hline Cabinet & $\mathrm{CA}$ & $\begin{array}{l}\text { Actors that are part of the ministries of the Execu- } \\
\text { tive Branch, bodies responsible for formulating } \\
\text { policies. }\end{array}$ \\
\hline Civil Society & CS & $\begin{array}{l}\text { Actors who are not part of the federal, state or local } \\
\text { administration or represent foreign governments. }\end{array}$ \\
\hline $\begin{array}{l}\text { Executive } \\
\text { Agency }\end{array}$ & EA & $\begin{array}{l}\text { Actors that are part of the federal autarchies, that } \\
\text { is, public entities with their own legal personality } \\
\text { and administrative autonomy (i.e., ANVISA and the } \\
\text { Central Bank of Brazil). }\end{array}$ \\
\hline $\begin{array}{c}\text { Foreign } \\
\text { Diplomacy }\end{array}$ & FD & Actors representing foreign governments. \\
\hline $\begin{array}{l}\text { Institutional } \\
\text { Presidency }\end{array}$ & IP & $\begin{array}{l}\text { Actors who work in agencies that operate under } \\
\text { direct presidential authority and are in charge of } \\
\text { supporting the presidential leadership (MOE, 1993; } \\
\text { DICKINSON, 2005; INÁCIO and LLANOS, 2016). }\end{array}$ \\
\hline Judicial Branch & $\mathrm{JB}$ & Actors that make up the judicial institutions. \\
\hline
\end{tabular}




\begin{tabular}{|c|c|l|}
\hline $\begin{array}{c}\text { Legislative } \\
\text { Branch }\end{array}$ & LB & Federal deputies, State deputies and Senators. \\
\hline $\begin{array}{c}\text { Local } \\
\text { Government }\end{array}$ & LG & Actors linked to local governments. \\
\hline $\begin{array}{c}\text { Subnational } \\
\text { Government }\end{array}$ & SG & Actors linked to subnational governments. \\
\hline
\end{tabular}

Source: Prepared by Author.

As figure 3 shows, in one-on-one and small group meetings, with an average last of 37 and 43 minutes, respectively, there was a predominance of actors from the Legislative Branch and the Cabinet. On the other hand, ten civil society actors participated in one-on-one meetings, while twenty-nine of them interacted with the president in small group meetings, evidencing that the second type of meeting is the pattern of interaction between the president and the civil society. For the other actors, the same pattern of interaction occurs in both types of meetings.

Figure 3. Actors by organizational affiliation and type of meeting.

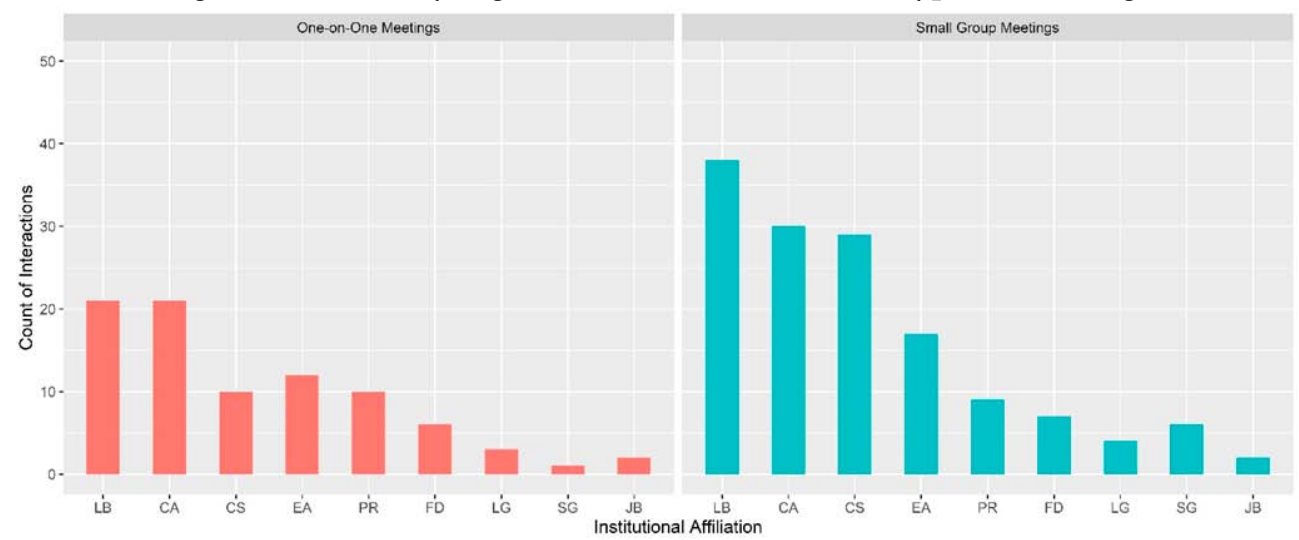

Source: Prepared by author.

A research on presidential advising points out that the frequency of interactions can reveal the circle of actors closest to the president and, therefore, are more central to the decision-making process ${ }^{70}$. Figure 4 shows that the actors with whom the president Bolsonaro interacted most during this period are the members of the presidency and the cabinet. In both one-on-one and small group meetings, the frequency of interaction with these two actors highly reveals that the president did not completely delegate the relation with cabinet ministers to the presidency units responsible for political coordination, such as the Government Secretariat and the Civil House. This measure was obtained by calculating the number of times that the name of each actor appears on the President's Daily Diary. 
Figure 4. Interactions by organizational affiliation and type of meeting.

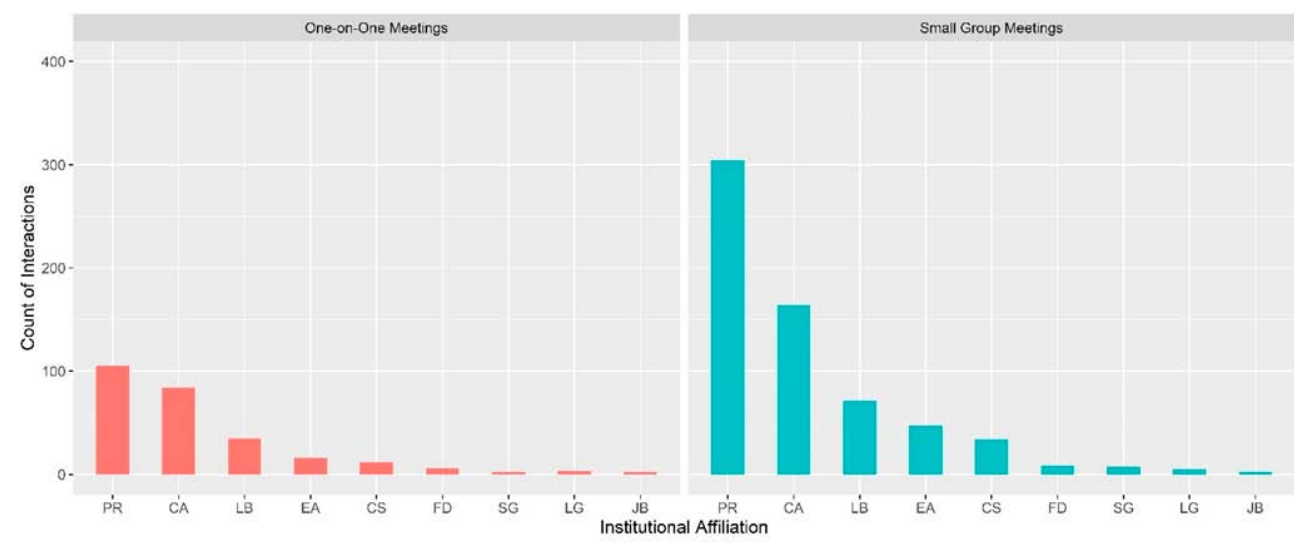

Source: Prepared by author.

In the president's interactions with cabinet members, different actors predominated in each type of meeting. In one-on-one meetings, the president interacted more intensively with the Justice and Public Security Minister, Sérgio Moro (CA) (15.48\%), the Education Minister, Abraham Weintraub (CA) (13.10\%) and Infrastructure Minister, Tarcísio Freitas (CA) (10.71\%). In small group meetings, in turn, the Economy Minister, Paulo Guedes (CA) (22.56\%), the Foreign Affairs Minister, Ernesto Araújo (CA) (14.02\%), the Regional Development Minister, Rogério Marinho (CA) (7.32\%) and the Special Advisor to the General Controller of the Union (CGU), André Mendonça (CA) (7.32\%). Except the Minister Rogério Marinho, all the others have no party affiliation.

These data reveal two patterns of presidential interaction over the period: (1) frequent relations with a relatively small group of seven ministers, and (2) unusual relations with the Health Minister - 5.95\% in one-on-one meetings and $4.27 \%$ in small group meetings, which is markedly low in comparison to the ministers mentioned above.

In Brazil, the Health Minister is the national manager of the Sistema Único de Saúde (SUS), being a pivotal actor in advising the President on national public health policies. Besides, he is in charge of leading the national public health emergency (Decree $7.616 / 2011$ ). Founded in 1988 , by the Federal Constitution, the SUS is a universal publicly funded health care system that offers services of high and low complexity all over the country. Its management is tripartite, sharing responsibilities between the Union, States and Municipalities, and its bureaucracies and leaders are recruited from professionals and specialists from the scientific health community. This country's state capacity in public health ensures a continuous flow of information to presidents, which can assist them in decision making process. However, the low interaction of President Bolsonaro with the Health Minister indicates that this information channel was not very mobilized at the beginning of the pandemic. 
Still, the frequency of the president's interactions with cabinet ministers has been used as an indicator of the president's pursuit to coordinate directly the formulation of the legislative agenda ${ }^{71}$. Research shows a positive association between the interaction's frequency of the Brazilian president with his ministers and the formulation of legislative agenda aligned with the priority agenda of the president ${ }^{72}$. Thus, the data point out that the President has not become the Health Minister his primary interlocutor, as well as he did not seek to coordinate directly the MOH's agenda to align it with his preferences.

The low frequency of interaction between the president and the Health Minister can be better understood in the context of the conflict of preferences between them. Since the beginning of the pandemic, both actors accumulated a series of conflicts. Appointed by President Bolsonaro to head the $\mathrm{MOH}$ during the government transition, Luiz Henrique Mandetta took office with the support of entities of the private health sector and the Parliamentary Health Front (FPS). When the Covid-19 outbreak started, he completed his first year as a minister, with the support of a team of professionals with health management experience. Face the pandemic, the minister took the lead in actions to combat the spread of the virus. Still, on early February, he issued the Ordinance 188, 2020 declaring the ESPIN and sent to the National Congress the Bill of Law with sanitary measures on social distancing and quarantine, compulsory medical examinations and vaccination, and restriction on entering and leaving the country. On March 27th, he authorized the publication of the protocol for the use of chloroquine and hydroxychloroquine for severe cases of coronavirus ${ }^{73}$.

However, the measures taken by the minister contradicted the preferences of President Bolsonaro, who is an open apologist against the social distancing measures and the widespread use of chloroquine and hydroxychloroquine for the treatment of non-severe cases of coronavirus. Faced to Mandetta responses, the President Bolsonaro began to make public statements contrary to the minister's guidelines. Bolsonaro went so far as to say that "Mandetta wants to assert his own will very much" ${ }^{74}$. This intra-Executive conflict underlies the low interaction between the president and the minister.

71. BATISTA Y CAVALCANTE (2018).

72. BATISTA Y CAVALCANTE (2018).

73. MINISTÉRIO DA SAÚDE. "Ministério da Saúde autoriza uso de cloroquina para casos graves de coronavírus". Available in: https://www.gov.br/pt-br/noticias/saude-e-vigilancia-sanitaria/2020/03/ ministerio-da-saude-autoriza-uso-de-cloroquina-para-casos-graves-de-coronavirus [Date of access: 05/01/2021].

74. URIBE y CANCIAN (2020): "Está faltando um pouco mais de humildade ao Mandetta, diz Bolsonaro sobre ministro da Saúde". Available in: https://www1.folha.uol.com.br/poder/2020/04/ esta-faltando-um-pouco-mais-de-humildade-ao-mandetta-diz-bolsonaro-sobre-ministro-da-saude.shtml [Date of access: 30/10/2020]. 
Regarding the president's interactions with members of the Presidency, almost the same actors predominated in each type of meeting. In one-on-one meetings, who present the greatest access to the president is the Presidency Secretariat Minister, Jorge Antônio de Oliveira (PR) (29.52\%), the Government Secretariat Minister, Luiz Eduardo Ramos (PR) (18.10\%) and the Civil House Minister, Braga Neto (PR) (15.24\%). While in small group meetings, it is minister Luiz Eduardo Ramos (PR) (36.84\%), again Braga Neto ${ }^{75}$ (PR) (22.04\%) and the Institutional Security Office Minister, Augusto Heleno (PR) (17.11\%).

The president's interactions with members of the Presidency are associated with the formal position they occupy ${ }^{76}$. These actors, who occupy the top of the formal organizational hierarchy of the Executive Branch, are responsible for providing information to the president, for political coordination with the cabinet ministries, with the Legislature and the subnational governments. In addition, they are not subject to the dynamics of the coalition, that is, they are not indicated by the allied parties in exchange for legislative support for the agenda of the Executive Branch in the National Congress, constituting in the most loyal group to the president ${ }^{77}$.

In the president's interactions with members of the Legislative Branch, different actors predominated in one-on-one and in small groups meetings. In one-on-one meetings, the president interacted more frequently with deputies Vitor Hugo (LB) (17.14\%), Marco Feliciano (LB) (11.43\%) and Otoni de Paula (LB) (11.43\%). In small group meetings, in turn, the most intense interactions are with deputies Fábio Faria (LB) (12.68\%), Vitor Hugo (LB) (9.86\%) and Osmar Terra (LB) (7.04\%) ${ }^{78}$. Especially the deputy Osmar Terra is known by making public statements criticizing the MOH's guidelines on pandemic. Among these five deputies, four of them are leaders and vice-leaders of the government in the Legislative Branch, responsible for defending the Executive Branch's agenda in the Legislature and for informing the president about the atmosphere in that house. Deputy Fábio Faria, despite not being a leader or viceleader of the government, was responsible for building the president's dialogue with the center-right parties of the Congress during the emergency. On June 2020, Bolsonaro appointed him to head the new Ministry of Communications.

\footnotetext{
75. On February 18, 2020, General Braga Neto was appointed as Civil House Minister, replacing Minister Onyx Lorenzoni. The data classification took this fact into account.

76. LINK (2002).

77. INÁCIO $(2012,2018)$.

78. Until February 23, 2020, Osmar Terra was Minister of Citizenship, who was replaced by Minister Onyx Lorenzoni, and returned to his deputy term. The categorization of the data took this fact into account.
} 
In the president's interactions with actors from the Executive Agencies, the same actors predominated in one-on-one and in small groups meetings. In one-on-one meetings, the president interacts more frequently with ANVISA's director, Antônio Barra Torres (EA) (18.75\%), with the Manaus Free Trade Zone Superintendent (SUFRAMA), Alfredo Menezes (EA) (12.50\%), and DataPrev's director, Gustavo Canuto (EA) $(12.50 \%)$. In small group meetings, the greatest frequency of interaction is again with the director of ANVISA (25.53\%), with Pedro Guimarães (EA) (17.02\%), president of Caixa Econômica Federal, a public Brazilian finance institution, and Gilson Machado (EA) (12.77\%), director of Brazilian Tourist Board (EMBRATUR).

In the president's interactions with members of the Civil Society, different actors predominated in each type of meeting. In one-on-one meetings, the president interacted more frequently with the actress Regina Duarte $(16.67 \%)^{79}$ and with the lawyer Karina Kufa (16.67\%). In small group meetings, the most frequent interactions were again with the lawyer Karina Kufa $(8.82 \%)$ and the actress Regina Duarte (5.88\%), and also with the president of the Brazilian Medical Association (AMB), Lincoln Ferreira (5.88\%), and the immunologist Nise Yamaguchi (5.88\%). Figure 5 shows President Jair Bolsonaro's network with civil society actors. Graph A represents the president's relations with civil society actors ins small group meetings, and graph B presents the president's relations in one-on-one meetings.

Both graphs reveal the pattern of interaction between President Bolsonaro and representatives of civil society, which were categorized according to their professional background into five categories (represented by each color). This pattern is marked by the greater presence of representatives of the national business sector, evangelical leaders and actors with different backgrounds (such as actress, soccer coach, broadcaster and journalist). Only four representatives from the health area are part of the president's network, and only one of them participated in one-on-one meetings with the president. This pattern is also marked by the lower interaction with health actors, as indicated by the percentage plotted in the ties between the president and each actor.

The professional background of civil society actors who attended the one-on-one meetings shows that $40.0 \%$ of them are lawyers, $20.0 \%$ are representatives of national business, and $10.0 \%$ belong to the health area. Yet, among the twenty-nine actors that participated in small group meetings, $37.9 \%$ of them are representatives of foreign and national business, while only $13.8 \%$ are from the health area, as figure 5 shows.

79. The actress was appointed as Culture Secretary on March 2, 2020, ceasing to be part of Civil Society and becoming a part of the Cabinet. The categorization of the data took this fact into account. 
Figure 5. Network of interactions of the Brazilian president from January to April, 2020.

A - SMALL GROUP MEETINGS

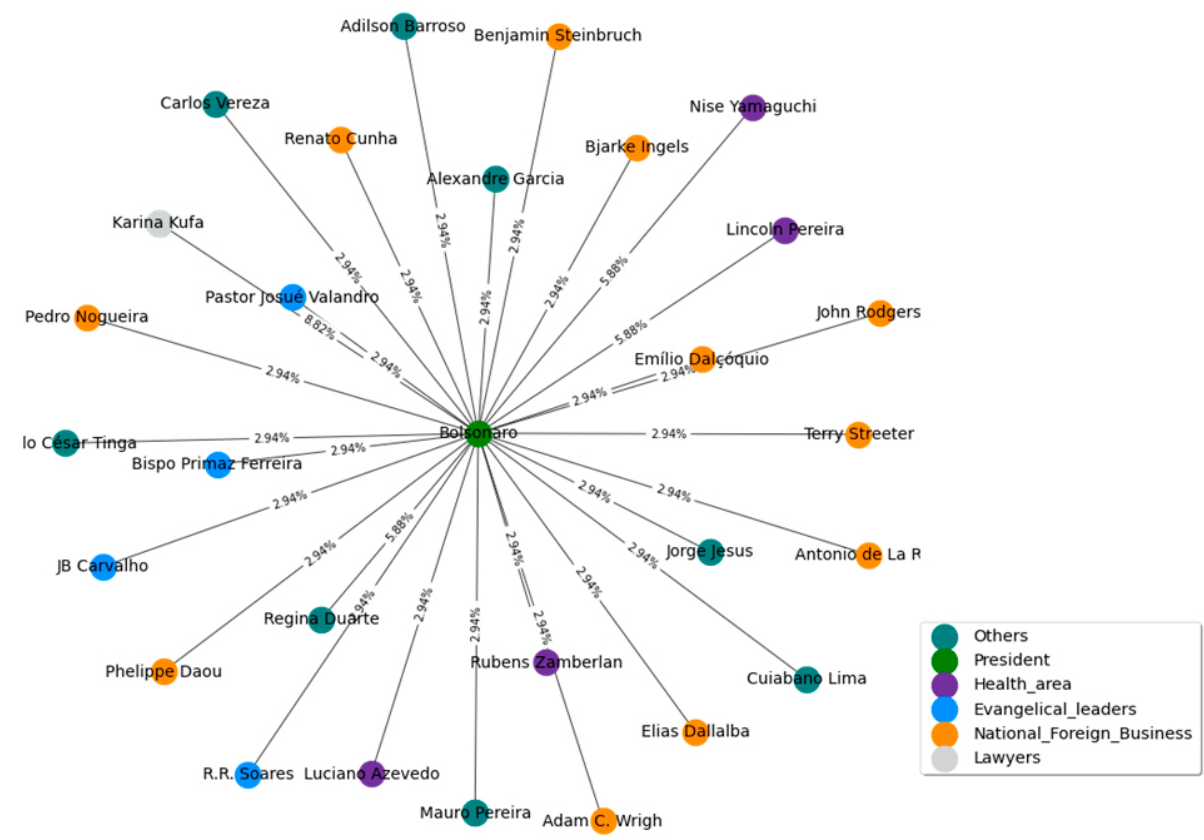

B - ONE-ON-ONE MEETINGS

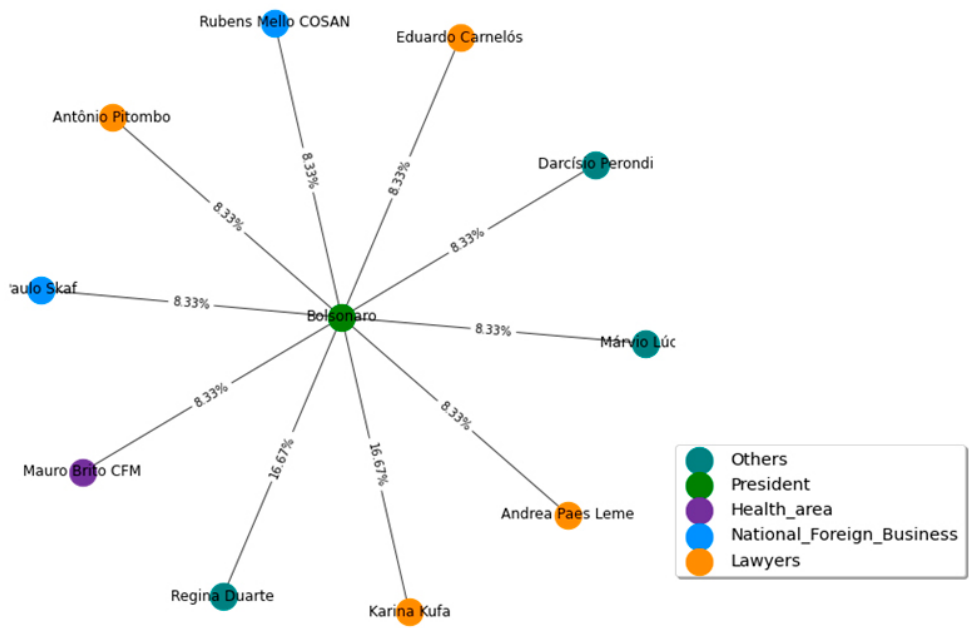

Source: Prepared by author. 
Graph A represents President Jair Bolsonaro's personal network (ego network) in small group meetings. This network has 29 actors and 34 interactions. Graph B represents President Bolsonaro's personal network in one-on-one meetings, which has 10 actors and 12 interactions. The percentages plotted on the edges represent the frequency of the president's interaction with each actor in each type of meeting. The nodes in the graphs represents each actor and each edge represents the relationship established between the nodes. Partial networks, such as those represented in figure number 5, present only the direct relations of an individual (namely ego, positioned in the center of the network) with his alters (that is, actors with which the ego establishes direct relations). These networks reveal the patterns of interaction or sociability of the ego. Here, in particular, partial networks reveal the pattern of interaction between President Bolsonaro (ego) and representatives of civil society (alters).

Among health actors, Doctors Nise Yamaguchi and Luciano Azevedo are known for their favorable position to the widespread use of chloroquine and hydroxychloroquine for the prevention and treatment of Covid-19. These actors (2020) accessed the president on April 6th and 7th two weeks after the publication of the protocol for the use of chloroquine and hydroxychloroquine by the $\mathrm{MOH}$, and one week before the resignation of Minister Mandetta. Their trajectory as researcher points up the potential informational role they played in the interactions with the president, providing a counterpoint to the information of the $\mathrm{MOH}$ on the use of the medicine. However, the president's first official statement in television and radio networks ${ }^{80}$ showed his favorable position to the widespread use of the medicine, occurred on March 24, twelve days before meeting these actors. Thus, these interactions better indicate a presidential strategy of signaling his preferences to the medical sectors that shared the same position on this issue.

In turn, the president of the Brazilian Medical Association (AMB), Lincoln Ferreira, interacted twice with the president Bolsonaro on April 16th, one day before the resignation of the Health Minister. Evidence points out that he was being quoted to take over the $\mathrm{MOH}$ replacing Mandetta, what finally did not happen. His professional background, especially his institutional role as a representative of the medical professionals, and the date of meetings with the president reinforces the noises about his appointment to head of the $\mathrm{MOH}$.

80. Available in: https://www.gov.br/planalto/pt-br/acompanhe-o-planalto/pronunciamentos/pronunciamentos-do-presidente-da-republica/pronunciamento-em-cadeia-de-radio-e-televisao-dosenhor-presidente-da-republica-jair-bolsonaro [Date of access: 11/01/2021]. 
The president of Federal Council of Medicine (CFM), Mauro Britto, interacted with president Bolsonaro on April 23rd, after an urgent hearing requisition with the objective of delivering Parecer No. $040 / 2020^{81}$ with recommendations on the possibility of using chloroquine and hydroxychloroquine for the treatment of Covid-19. The entity's position was to authorize the use of the medicine for severe and mild cases of the disease. This meeting occurred at the height of the discussion on the use of the chloroquine and hydroxychloroquine in the country, but one month after the president to defend the widespread use of the medicine in an official statement ${ }^{82}$.

The president of the Hospital Vida \& Saúde, Rubens Zamberlan, interacted with the president on January 15th, 2020. At that time, $\mathrm{MOH}$ was monitoring the evolution of the virus in the world and starting to preparedness and response phase, as a chronology of events show (Figure 2). There is no evidence that Covid-19 was under the president's radar of concern. Evidence also indicates that the main agenda of the meeting was the invitation to the president for the inauguration of a new unit of Hospital Vida \& Saúde in the municipality of Santa Rosa, without any relation to emergency measures to contain Covid-19 ${ }^{83}$.

Figure 6 shows that the health actors that attended small group meetings also interacted with members of the Cabinet, the Presidency, the Legislative Branch, the Executive Agency and the National Business. The government agents may have played a role as network brokers, facilitating the access of the health actors to the president.

81. The official statement is available in: https:/www.gov.br/planalto/pt-br/acompanhe-o-planalto/ pronunciamentos/pronunciamentos-do-presidente-da-republica/pronunciamento-em-cadeia-deradio-e-televisao-do-senhor-presidente-da-republica-jair-bolsonaro [Date of access: 12/01/2021]. 82. Available in: http://www.hvidaesaude.org.br/noticia/rubens-zamberlan-entrega-convite-parabolsonaro [Date of access: 10/01/2021].

83. Available in: http://www.hvidaesaude.org.br/noticia/rubens-zamberlan-entrega-convite-parabolsonaro [Date of access: 10/01/2021]. 
Figure 6. Network of interactions of the Brazilian president health actors in small group meetings from January to April, 2020.

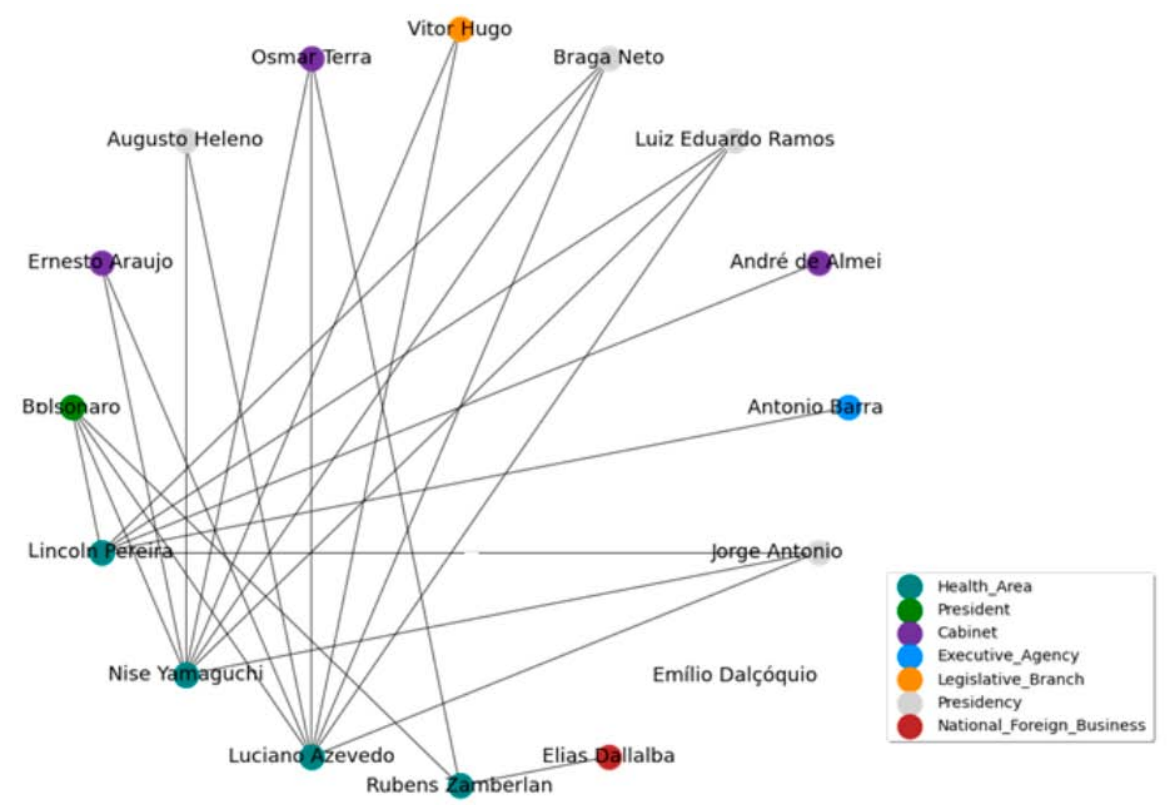

Source: Prepared by author based on TUMELERO Database available in: https://doi. org/10.6084/m9.figshare.14200337.

Figure 6 shows the complete network of the President Bolsonaro (ego) and members of the health sector in small group meetings. The nodes in the graphs represent the actors and the edges represent the relationship established between the nodes. Complete networks present not only the direct relations of the ego with his alters, but also the indirect relations of the ego produced by relations of the alters with other individuals that make up the relational space. Here, in particular, the alters of the health representatives are presented. These alters are members of the Cabinet and the Legislative Branch, which reveals that the government actors are intermediaries between the president and the members of the health area. 


\section{Discussion}

The informational scenario that surrounded the president at the beginning of the pandemic was pointed by four features. First, the president chose not to mobilize $\mathrm{MOH}$ as his main information channel during the crisis, despite the portfolio is in charge of the public health emergency management. This presidential option is reinforced by the records of President's Daily Diary. From January to April (2020), the president interacted twelve times with the Health Minister - seven in small group meetings and five in one-on-one meetings - a less frequency than the interactions with the Justice Minister, Education Minister and Infrastructure Minister.

Second, the president used his unilateral powers to access information about the outbreak, centralizing in the Presidency the Crisis Committee for Supervision and Monitoring the Impacts of Covid-19, an advisory arrangement created in March that is not part of the disaster's governance structure. In addition, the president initially chose to compose the Committee with twenty-two representatives of the Federal Administration, 16 of whom are representatives of the cabinet, 4 representatives of the Public Banks and only 2 of the health sectors. There were not representatives of civil society linked to the health area appointed to the Committee, which could provide alternative sources of information for the president.

Third, the Presidency advisory structures, especially the Civil House, the Government Secretariat and the Presidency Secretariat, were the main informational support of the president during the emergency, playing a central role in the presidential advisory network. From January to April, there were 4.09 interactions by members of these structures with the president, being 304 in small group meetings and 105 in one-on-one meetings, while there were 248 interactions between the president and cabinet ministers. The centrality of these actors in the advisory network was expected considering that they are the most loyal contingent to the president. In addition, the centralization of the Crisis Committee for Supervision and Monitoring the Impacts of Covid-19 further strengthened the Presidency's informational capacity.

Fourth, civil society actors accessed the president during the outbreak. The analysis of their professional background reveals five patterns of interaction: (1) frequent interactions with actors linked to national and foreign business; (2) frequent interactions with evangelical leaders; (3) frequent interactions with lawyers; and finally, (4) with health actors. Applying the methodological framework developed in the $4^{\text {th }}$ section, it is not possible to say that an informal advisory network was mobilized by the president as a channel for transferring and exchanging information alternative to the MOH from January to April, 2020.

When interactions with health actors were registered in the President's Daily Diary, the president's opposition to the MOH's recommendations was already publicly known. Still, most of the health actors are known for their contrary position to the 
social distancing measures and the protocol for the use of chloroquine and hydroxychloroquine defined by the $\mathrm{MOH}$. Therefore, these interactions indicate better a presidential strategy of signaling of preference to the electoral base and not an informal advisory strategy. They also evidence that the president did not dialogue with health organizations that have different position about the measures to face the outbreak.

The informational context created by the Brazilian president differs markedly from the context created by leaders of other countries in face of the public health emergencies. The case of the $\mathrm{H}_{1} \mathrm{~N}_{1}$ outbreak in Mexico in 2009 highlights this difference. The Mexican President, Felipe Calderón, chose to act in accordance with the public health emergency governance structure (Article 181 of Ley General de Salud), delegating to the Health Minister the coordination of actions to face the outbreak. Leading the actions, the Health Minister established a daily calendar of meetings of the Consejo de Salubridad General and the Consejo Nacional de Salud. The meetings facilitated the coordination between all levels of government, fostering a joint decision-making process between government and civil society ${ }^{84}$. In other words, Calderón's informational context was marked by collegiate instances of experts, and a continuous flow of technical and scientific information to drive his decision making.

These findings provide evidence that contributes to understand how presidents of multiparty governments deal with agency losses produced by the delegation relationship. The case of Brazil reveals that the conflict of preference within the cabinet is not a sufficient incentive for the adoption of an informal advisory network by the president in the context of a national emergency. Rather, this specific context reinforced the president's use of his formal unilateral powers, first centralizing the Crisis Committee for Supervision and Monitoring the Impacts of Covid-19 in the presidency and then dismissing the Health Minister and appointing loyal personnel to head of the $\mathrm{MOH}$.

However, it is important to ponder the findings regarding the data source of the study. Despite providing well documented, publicly available relational data, the Brazilian President's Daily Diary is only one piece of evidence on the informal advisory networks. Not all types of the president interactions - e.g., phone calls and emails - are registered in it. Thus, the President's Daily Diary may not reveal all the characteristics of the informal advisory network, especially all actors and interactions. To solve this gap, complementary data sources are needed such as in-depth interviews and institutional ethnography ${ }^{85}$.

84. CÓRDOVA-VILLALOBOS et al. (2009).

85. GAINS (2011); RANKIN (2017). 


\section{Conclusion}

In Brazil, evidence about the existence of informal presidential advisors abounds. Nevertheless, research on this topic is incipient. The purpose of this article was to develop a conceptual and methodological framework to identify and measure it, contributing to pave the way for the analysis of informal presidential advising in Latin America.

First, it provides a detailed concept of informal advisory networks based in three analytical attributes: (1) relational choices, (2) non-regulation by legal measures and (3) network structure. Thus, the informal advisory strategy refers to the network of relationships established by the presidents with small group of actors, who are external to government, as a means of accessing information. These interactions are not regulated by a legal provision and the network is constantly changing, with relationships being activated and deactivated at any time.

Second, it defines four empirical indicators to measure informal networks: (1) the type of meeting, especially one-on-one and small group meetings; (2) the organizational affiliation of the actors of network, which allows to identify the actors who have a formal advisory role and those whose advisory role is informal; (3) the actors' professional background, which indicates the potential capacity of actors to provide information on policy making; and (4) the temporal precedence of meetings regarding the decisions and positions adopted by the presidents.

This conceptual and methodological framework is applied to a case study of Brazilian president interactions in the first four months of the Covid-19 outbreak. This period was marked by the intra-executive conflict between the presidency and $\mathrm{MOH}$ portfolio in charge of public health emergency management - and it covers decisions of national importance on topics related to the pandemic, such as social distancing measures and the protocol for the use of chloroquine and hydroxychloroquine. The President's Daily Diary was used as source of evidence.

The findings reveal the informational scenario in which the Brazilian president was embedded during the emergency. The scenario was marked by three features. First, the choice of president by-passes the $\mathrm{MOH}$ as his main information channel, despite the portfolio being in charge of public health emergency management and leading responses to the outbreak from the beginning. Second, the president's option to use the structures of the Presidency as the main informational support - especially Civil House, the Government Secretariat and the Presidency Secretariat - besides strengthening its informational capacity through the centralization of a Crisis Committee. Third, his choice by not combining formal and informal advisory as the strategy to access information alternative to $\mathrm{MOH}$.

However, it is important to ponder these findings regarding the data source of the study. Provoked by this case there is one main lesson for the analysis of informal 
advisory networks. President's Daily Diary may not reveal all the interactions of presidents and as a result, it may omit the real existence of informal advisory networks. To solve this data gap, it is important to collect complementary data by in-depth fieldwork techniques.

\section{Referencias bibliográficas}

ALLISON, Graham (1971): Essence of Decision: Explaining the Cuban Missile Crisis (Boston, Little, Brown and Company).

AMORIM NETO, Octavio (1994): "Formação de Gabinetes Presidenciais no Brasil: Coalizão versus Cooptação". En Nova Economia, v 4, n 1, December, 2013, pp. o934.

AMORIM NETO, Octavio (2006): “The Presidential Calculus: Executive Policy Making and Cabinet Formation in the Americas" En Comparative Political Studies, $\mathrm{v}$ 39, n 4, May, 2006, pp. 415-440.

ARANA, Ignácio (2012): “¿Quién le Susura al Presidente? Asesores vs. Ministros en América Latina” En Revista de Ciencia Política, v 5o, n 2, January, 2012, pp. 33-61.

BATISTA, Mariana (2013): “O Poder no Executivo: uma Análise do Papel da Presidência e dos Ministérios no Presidencialismo de Coalizão Brasileiro (1995-2010)" En Opinião Pública, v 19, n 2, pp. 449-73.

BATISTA, Mariana y CAVALCANTE, Pedro (2018): "Como Governam os Presidentes: a Governança do Executivo e a Formulação da Agenda Legislativa”. En: CAVALCANTE, Pedro; GOMIDE, Alexandre (eds.) O Presidente e seu Núcleo de Governo - A Coordenação do Poder Executivo (Brasília, IPEA).

BEST, James (1988): "Who Talked to the President When? A Study of Lyndon B. Johnson”. En Political Science Quarterly, v 103, n 3, pp. 531-545.

BEST, James (1992): "Who Talked with President Kennedy? An Interaction Analysis". En Presidential Studies Quarterly, v 22, n 2, pp. 351-369.

CRODA, Julio y GARCIA, Leila. (2020): "Immediate Health Surveillance Response to COVID-19 Epidemic". En Revista de Epidemiologia e Serviços de Saúde, v 29, n 1, March 2020, pp 1-3.

CÓRDOVA-VILLALOBOS José, SARTI, Elisa, ARZOZ-PADRÉS, Jaqueline, MANUELL-LEE, Gabril, MÉNDEZ y Josefina, KURI-MORALES, Pablo. (2009): “The Influenza $\mathrm{A}\left(\mathrm{H}_{1} \mathrm{~N}_{1}\right)$ Epidemic in Mexico - Health Research Lessons Learned”. En Health Research Policy and Systems, September, 2009, pp. 7-21. 
GAINS, Francesca (2011): "Elite Ethnographies: Potential, Pitfalls and Prospects for Getting up Close and Personal". En Public Administration Review, v 89, n 1, pp. 156-166.

GAYLORD, Sylvia y Lucio RENNÓ (2015): "Opening the Black Box: Cabinet Authorship of Legislative Proposals in a Multiparty Presidential System”. En Presidential Studies Quarterly, v 45, n 2, pp. 247-69.

GOLDHAMER, Herbert (1978): The Adviser (New York: Elsevier).

HELMKE, Gretchen y LEVITSKY, Steven (2006): Informal institutions and Democracy: Lessons from Latin American (Baltimore. The Johns Hopkins University Press).

INÁCIO, Magna (2012): “Coalition Governments and the Institutional Development of the Presidency in Brazil". En Paper presented at Special Seminars, University of Oxford, Latin American Centre, September, 2012.

INÁCIO, Magna (2013): “Coalition Governments and the Institutional Development of the Presidency in Brazil". Paper presented at71st Annual Midwest Political Science Association Conference, Chicago, 2013.

INÁCIO, Magna (2018): “Centro presidencial en Brasil” En: LANZARO, Jorge. (ed.) En Centro Presidencial: Presidencias y Centros de Gobierno en América Latina, Estados Unidos y Europa (Madrid, Tecnos).

INÁCIO, Magna y LLANOS, Mariana (2015): “The Institutional Presidency in Comparative Perspective: Argentina and Brazil Since the 1980s". En Brazilian Political Science Review, v 9, n 1, pp. 39-64.

INÁCIO, Magna y LLANOS, Mariana (2016): “The Institutional Presidency in Latin America: A Comparative Analysis". En Presidential Studies Quarterly, v 46, n 3, pp. 531-549.

KELLER, Franziska (2015a): "Moving Beyond Factions: Using Social Network Analysis to Uncover Patronage Networks among Chinese Elites". En Journal of East Asian Studies, v. 16, n 1, March 2016, pp. 17-41.

KELLER, Franziska. (2015b): "Networks of Power: Using Social Network Analysis to understand who will rule and who is really in charge in the Chinese Communist Elites (1982-2012)". Presented at APSA Meeting, 2014.

KOWERT, Paul A. (2002): Groupthink or Deadlock. When Do leaders Learn from Their Advisors? (New York: State University of New York Press). 
LEWIS, David (2003): Presidents and the Politics of Agency Design: Political Insulation in the United States Government Bureaucracy, 1946-1997 (Palo Alto, Stanford University Press).

LINK, Michael y KEGLEY, Charles (1993): "Is Access Influence? Measuring Adviserpresidential Interactions in Light of the Iranian Hostage Crisis". En International Interactions: Empirical and Theoretical Research in International Relations, v 18, n 4, pp. 343-364.

LINK, Michael (2002): “The Presidential Kaleidoscope: Advisory Networks in Action”. En: SHAPIRO, Robert et al (eds.). Presidential Power: Forging the Presidency for the Twenty-First Century (New York, Columbia University Press).

LINZ, Juan y VALENZUELA, Arturo (1994): The Failure of Presidential Democracy: he Case of Latin America (Baltimore, The Johns Hopkins University Press).

MAINWARING, Scott (1993): "Presidentialism, Multiparty Systems and Democracy: The Difficult Combination". En Comparative Political Studies, v26, issue 2, pp. 198228.

MOE, Terry (1985): The Politicized Presidency. En: CHUBB, John, PETERSON, Paul (ed.) The New Direction in American Politics (Washington, Brookings Institution Press).

MOE, Terry (1993): Presidents, Institutions and Theory. En: KESSEL, John (ed.) Researching the Presidency: Vital Questions, New Approaches (Pittsburgh, University of Pittsburgh Press).

MOE, Terry (2000): The Presidency and the Bureaucracy: The Presidential Advantage. En: NELSON, Michael (ed.) The Presidency and the Political System (Washington, Congressional Quarterly Press).

Moe, Terry (2009): “The Revolution in Presidential Studies”. En Presidential Studies Quartely, v 39, n. 4, pp. 701-724.

MOE, Terry y CALDWELL, Michael (1994): “The Institutional Foundations of Democratic Government: A Comparison of Presidential and Parliamentary Systems". En Journal of Institutional and Theoretical Economics (JITE), v 150, n 1, pp. 171-195.

MAQUIAVEL, Nicolau (2013): O Príncipe (Petrópolis: Editora Vozes).

MELTSNER, Arnold (1990): Rules for Rulers: The Politics of Advice (Philadelphia: Temple University Press).

MÉNDEZ, José Luiz (2007): "La Oficina Presidencial y el Liderazgo Político en Mexico y Estados Unidos”. En Foro Internacional 190, XLVII, pp. 839-867. 
NEUSTADT, Richard (1991): Presidential Power and The Modern Presidents: The Politics of Leadership from Roosevelt to Reagan (New York: Free Press).

PIOUS, Richard (2001): “The Cuban Missile Crisis and the Limits of Crisis Management”. En Political Science Quarterly, v 116, n 1, pp. 81-105.

RANKIN, Janet (2017): "Conducting Analysis in Institutional Ethnography: Guidance and Cautions". En International Journal of Qualitative Methods, v 16, n 1, October, 2017, pp.1-11.

RAZO, Armando (2008): Social Foundations of Limited Dictatorship: Networks and Private Protection During Mexico's Early Industrialization (Palo Alto: Stanford University Press).

STARGARDTER, Gabriel y EISENHAMMER, Stephen (2020): "Special Report: Bolsonaro brought in his generals to fight coronavirus. Brazil is losing the battle". Disponible en: https://www.reuters.com/article/us-health-coronavirus-brazilresponse-sp/special-report-bolsonaro-brought-in-his-generals-to-fight-coronavirus-brazil-is-losing-the-battle-idUSKBN2321DU [Fecha de consulta: 12 de enero de 2021].

RODRIGUES, Karina, CARPES, Mariana y RAFFAGNATO, Carolina. (2020): "Disaster Preparedness and Response in Brazil in The Face of the COVID-19 Pandemic". En Brazilian Journal of Public Administration, v 54, n 4, August, 2020, pp.614-634.

RUDALEVIGE, Andrew (2002): Managing the President's Program: Presidential Leadership and Legislative Policy Formulation (New Jersey: Princeton University Press).

RUDALEVIGE, Andrew y DAVID E. Lewis (2005): "Parsing the Politicized Presidency: Centralization, Politicization, and Presidential Strategies for Bureaucratic Control". Paper presented at the Annual Meeting of the American Political Science Association, Washington, DC, 2005.

SIAVELIS, Peter (2014): "The Fault Lines of Coalitional Presidentialism: Cabinets, Quotas, Iron Circles and the Second Floor in Chile". Paper prepared for the 23rd World Congress of the International Political Science Association, Montreal, Cana$d a$, March 17-18, 2014.

SIAVELIS, Peter (2016): "Cabinets and Informal Advisory Networks in Multiparty Presidential Systems". En Presidential Studies Quarterly, v 46, n 3, pp. 569-591.

SIGELMAN, Lee y MCNEIL, Dixie (1980): “White House Decision-Making Under Stress: A Case Analysis". En American Journal of Political Science, v 24, n 4, pp. $652-673$. 
T'HART, Paul, TINDALL, Karen y BROWN, Christer (2009); “Crisis Leadership of the Bush Presidency: Advisory Capacity and Presidential Performance in the Acute Stages of the 9/11 and Katrina Crises". En Presidential Studies Quarterly, v 39, n 3, pp. 473-493.

THOMAS, Norman (1970): "Presidential Advice and Information: Policy and Program Formulation". En Law and Contemporary Problems, v35, n3, p. 540-572.

THOMPSON, Robert J. (1990a): "Eisenhower the Effective Management of the Presidency and Its Legacy: An Empirical Analysis". Paper presented at the Dwight D. Eisenhower Symposium, Gettysburg College, Gettysburg, October 11-13, 1990.

THOMPSON, Robert J. (1990b): “The Spokes of the Wheel in Operation: The Carter Example". Paper presented at the Eighth Presidential Conference, Hofstra University, Hampstead, New York, November 15-17, 1990.

THOMPSON, Robert J. (1990c): "Contrasting Models of White House Staff Organization: The Eisenhower, Ford, and Carter Experiences". En Congress \& the Presidency, v 19, n 2, pp. 113-136.

URIBE, Gustavo; CANCIAN, Natália (2020): "Está faltando um pouco mais de humildade ao Mandetta, diz Bolsonaro sobre ministro da Saúde”. Disponible en: https:// www1.folha.uol.com.br/poder/2020/o4/esta-faltando-um-pouco-mais-de-humildade-ao-mandetta-diz-bolsonaro-sobre-ministro-da-saude.shtml [Fecha de Consulta: 11 de diciembre de 2020].

WALTHER, Oliver (2015): "Social Network Analysis and Informal Trade". En Department of Border Region Studies Working Paper Series n1/15, April, 2015, pp. 01-18.

WASSERMAN, Stanley; FAUST, Katherine (1994): Social Network Analysis - Methods and Applications (Cambridge: Cambridge University Press).

WITHERSPOON, Patricia (1991): Within these walls: A study of communication between presidents and their senior staff(Westport, Praeger). 